\title{
The relationship between financial development indicators and human capital in Iran
}

\author{
Hamed Adeli Nik ${ }^{*}$, Zahra Sattari Nasab, Yunes Salmani and Nima Shahriari
}

Department of Progress Engineering, Iran University of Science \& Technology, Tehran, Iran

\section{H R O N I C L E}

Article history:

Received October 27, 2012

Received in revised format

29 January 2013

Accepted 19 February 2013

Available online

February 242013

Keywords:

Human Capital

Financial development Indicators

VAR

Iran

\section{A B S T R A C T}

Human capital is considered as one of the major factors to promote economic stability, especially in developing countries. Furthermore, one of the most important factors in developing human capital is taking the advantage of facilities and economic capabilities in education. Development of financial system provides such abilities for the prospective countries. This paper studies the influence of financial development on human capital in Iran over the period 1977-2010 with the application of a VAR model. The results indicate the cash flow in Iran has a negative effect on human capital, which is the main cause of the increase in inflation. Education is a long term investment and when inflation hikes, people switch to alternative investments. However, the facilities provided by the banking system has negative effect on human capital due to the lack of the best financial resource allocation. However, since most of university graduate students in Iran practically have adequate skills and education, they do not have enough capital to start a business. Providing financial assistance for the private sector can lead to a business in which they can use their skills and education towards promoting production. Financial development could only slightly contribute to human developments.

\section{Introduction}

According to the economic theories, the role of human labor in the process of production has had noticeable changes during the past. This change contains the concept of labor force, which only evaluates the physical abilities from one side and the human capital from the other side, which is the result of stored knowledge of skills and experience in humans. Furthermore human capital issue in economy has an increasing importance in effective stability. This has been the only reason for many different countries to imply their economic capabilities and abilities to promote human capital, while conducting the financial sources towards human capital development, which is more outstanding in developing countries. However, developing financial markets in Iran, which indicates its rate of efficiency in accessible financial system would be highly indicative in human capital. 


\subsection{Human Capital}

The acceptance of human capital as a main stream in economic literature goes back to the beginning of 1960s; when dominant economists throughout the world put an attempt to present a persuasive explanation for the economic development, which had remained an unexplainable matter. Human capital based on strong theoretical foundations as a main factor in production was entered into the economic development patterns during the late 1980s. Lucas (1988) is believed to be one of the pioneers in human capital development studies in recent years.

The initial intention of the theoretical human capital is that investments in human resources could lead to the enhancement of individual productivities, which ultimately improves economic development. Such thoughts resulted in a production function to enter this pattern including the quantity or quality of labor force, the quality of human force (such as formal educational qualifications and practical educations). However, in modern studies the capital conceptual growth has developed from the classical conditions in machineries and equipment to inverting in human resources.

The effectiveness of human capital on this growth could be imagined in two areas. One of them is investing in human resources, while other conditions are stable which could enhance individual productivity. This concept is of course the main theory of human capital based on the more human capital stored, the more production promotion accelerates. Note that these investments can drastically increase the production with the help of new technology transferred and its application. Therefore, we can provide the necessary paths for human capital to imply the imported technology to a larger scale.

As previously explained, human capital along with physical capital is considered as the most important factor for the economic growth. Human capital is an indication of efficiency in individuals as well as eligibilities and abilities, which are including knowledge, skills and experience that can be valuable in economy. Of course, human capital is a multi-dimensional concept, which can be planned in various forms such as Education, Health, Nutrition, Employment, Political freedom, Environment and Economical freedom. However, education is considered the fundamental source in this structure. Examples of acquired abilities in education are as follows:

- Sociable skills learned by the students to be more outgoing in public,

- Stability in social values,

- Forming ideologies towards social discipline,

- Work discipline,

- Flexibility,

- Accepting criticisms',

- Motivation to search and motives in cooperation with others.

Education plays essential role on fulfilling people's abilities and talents to increase their efficiency, productivity, etc. According to Wayne Nafziger (2006) "Schooling presents specific knowledge, develops general reasoning skills, causes values to change, increases receptivity to new ideas, and changes attitudes toward work and society". Therefore, it could be inferred that Education is a strong tool to enforce human capital as a vital factor in production. In other words, education is an equipment to strengthen humans for conscious choices, thus it could be consequently realized that peoples' education is a social economic necessity. There are many evidences to believe that education and human capital provide higher return compared with physical capital in developing countries (Psacharopoulos \& Woodhall, 1985; Psacharopoulos, 1985; Wayne Nafziger, 2006). 


\section{Human Capital Indicators}

There are different indicators in order to measure human capital below indicates some important indicators:

1. Average years of schooling; it is one of the most and best direct indicators to form human capital through-out the country. Gylfason ( 2001 ) and Zhang and Zhuang ( 2011) implied this indicator.

2. School enrollment, secondary (\% gross); The use of School enrollment, secondary (\% gross) as an indicator for human capital is Conventional in economic studies. (Mankiw et al., 1992; Gylfason, 2001; Birdsall et al., 2001; Anwar \& Cooray, 2012; Zaman et al. 2012). The above references have been using this indicator.

3. School enrollment, tertiary (\% gross); Zhang and Zhuang (2011) has been using this indicator in their study for human capital consideration in China.

4. Adult literacy Rate; Birdsall et al.(2001) and Davis (1995) have been using this indicator.

5. General expenditure on education; Gylfason (2001) used this indicator as a percentage of total expenses.

Although primary school education is important in developing countries but high school education and higher education should not be forgotten (Wayne Nafziger, 2006). In recent studies referring to human capital, the use of "school enrollment, tertiary" has been on the increase compared with the "School enrollment, secondary". However, School enrolment secondary (\% gross) is not a fruitful example of human capital in Iran since the secondary school education has been a nation- wide procedure. On the other hand, primary and secondary school education in Iran cannot provide individuals to acquire adequate social skills in order to make conscious choice. Therefore, the primary and the secondary school registration rate would not be a suitable indicator for human capital in Iran. Thus, in our studies we have used School Enrollment Tertiary (\%gross) as an indicator for human capital in Iran.

\subsection{Measurement of Financial Development}

One of the most important problems in measuring financial development is quantitative experimental calculations of financial development in the country. This problem arises from the concept of financial development such as the economic capacity and ability of a country to transfer savings towards investment inside the country, effectively and efficiently. This capacity depends on instances such as structural frame, Financial Markets Quantity, which differs from the implementation of Financial Markets in that country (Dorrucci et al., 2009).

In studies regarding financial development, different indicators have been taken in to account. Some of them are as follows:

1. $M_{1}$ (The ratio of Currency to narrow money Stock): Al-Yousif (2002), Kar et al.(2011),which generally benefited from this indicator.

2. The ratio of $\mathrm{M}_{2}$ to GDP (the ratio of "Broad money supply as percentage of GDP”): This indicator and the first indicator are the most efficient and the oldest indicators applied in financial development. Bittencourt (2012), Odhaimbo (2009), Ferda (2007), Kar et al. (2011), Zaman et al. 
(2012), Al- Yousif (2002), Gelb (1989) and King and Levine (1993) have used this indicator for financial development.

3. The ratio of "Domestic credit to private sector to GDP": Kar et al. (2011), Colombage (2009), Khan and Senhadji (2003), Zaman et al. (2012) and Gregorio and Guidotti (1995) have used this indicator.

4. The ratio of “Total loans in financial system to GDP”: Zhang et al. (2012) applied this indicator to consider the relationship between financial development and economic growth throughout different cities in China. Anwar and Cooray (2012) also applied this indicator to consider the relationships among financial development, political rights, civilian liberties and economic growth in south Asian countries.

5. The ratio of bank deposit liabilities to GDP: Ferda (2007), Qayyum (2007), Khan and Demetriades et al. (1996) benefited from this indicator for financial development. This indicator is also an appropriate substitution for a ratio of M2 to GDP.

6. The ratio of bank claims on the private sector to nominal GDP. Demetriades et al. (1996) and Ferda (2007) used this indicator in their studies.

7. The amount of capital as share of GDP by Stock Market Development. This indicator shows the range of development in Stock Market Zaman et al.(2012) have used it as an indicator for financial development. The Stock Market has an important role in capital allocation for the private sector in different countries (Shahbaz et al., 2008).

Three substituted indicators for financial development in Iran have been recommended in this article to consider the relation between financial development and human capital. Selecting indicators is based on to be access reliable data and it is also based on different aspects of financial development as well as the specifications of Iran Financial Economic Market. The nature of bank based of Iran's financial market, the inflationary financing of the economy and uncertainty conditions governing Iran's financial market including some of the Monetary Market specifications and Financial Economy in Iran. In addition, because the stock market has a relatively low share in the financing process in Iran, Stock market development indicator is not used in this paper.

Considerable aspects regarding Iran financial economy development in this article are such as :

- Degree of monetization in the economy.

- Accessible measures of financial system services for the private sector.

- Development of financial system in depth and developing financial sectors based on their sizes.

Three financial development indicators used in this paper are as follow:

1) The ratio of broad money supply as percentage of GDP. This indicator measures the degree of monetization in the economy. (Kar et al., 2011). This ratio measures the exact size of financial system in the country.

2) The domestic credit to private sector as percentage of GDP. Domestic credit to private sector is financial resources provided to the private sector such as through loans, purchases of nonequity securities, and trade credits and other accounts receivable that establish a claim for repairmen (WDI-2012, p. 287).

3) Domestic credit provided by banking sector (\% of GDP). Note that Iranian financial system depends strongly on banking system. This indicator is capable of illustrating the banking division in depth as well as financial division growth in the country. Therefore, we imply this ratio as another indicator for Iran economy. The application of this indicator has not been seen 
in similar studies. However, we apply this new indicator to consider financial development with regards to the specification of providing financial system in Iran economy.

The rest of this study is arranged in the following manner. Section 2 contains some related literature review. Data are described in Section 3. Empirical model and relevant econometrical discussions are mentioned in section 4 . Final section concludes the paper.

\section{Some relevant literature}

It has been indicated in different studies that there is a positive relation between economic development and financial development. Furthermore, the government restrictions on financial system have been an obstacle to develop, which leads to production growth decrease. (Shaw, 1973; McKinnon, 1973). A developed financial system would launch resources to the most possible effective form towards Economic Activities. In addition, with the reduction in transaction costs and costs related to supervising would promote economy towards a developed economy (Singh, 2007; Schumpter, 1911; Levine, 1997).

Zhang et al. (2012) used panel data method and GMM pattern to consider the relationship between the financial development and economic growth throughout the city with the application of related data for 286 cities in China over the period 2001-2006. However, the results of their research indicated that most indicators of traditional financial development had a positive relationship with the economic growth. Kar et al. (2011) considered the direction of casualty between financial development and economic growth about middle east and north African countries (MENA) by using the method of subjective test panel over the years 1980-2007. In order to consider different aspects of financial development, they applied six different indicators for financial development. The results of their research indicated that the direction of casualty relationship between financial development and Economic Growth depends on a kind of indicator to measure financial development and depends upon different countries. Christopoulos and Tsionas (2004) considered the long-term relationship between financial development end economic growth for ten developing countries. The results of their research studies indicate that there was a balanced relationship between financial development and Growth.

AL-Yousif (2002) performed an investigation on thirty developing countries over the period 19701999 and their results indicated that there was a bidirectional causality between financial development and Economic growth. Anwar and Sun (2011) studied the interrelationship among economic growth, the stock of foreign investment and financial development in Malaysia. They used annual data in their research during 1970-2007 with GMM method .The financial developments consequently ended the growth of the stock of domestic capital in Malaysia, however, the effect of this on economic Growth in this country was statistically insignificant.

Deidda (2006) studied whether financial development was sustainable and a more competitive credit market was created, which was more effective and more efficient over time. The relationship between economic development and human development has frequently been considered in both Experimental and theoretical studies. The studies of Benhabib and Spiegel (1994), Mankiw et al. (1992), Romer (1990), which emphasizes on the role of human capital in economic growth. Ranis et al. (2000) defined the relationship between economic growth (EG) and human development (HD) as two chained characteristics. Ranis (2004) introduced three kinds of paths towards the relationship between economic growth and human development.

1) The impact of Economic Growth on human development,

2) The impact of human development on Economic Growth,

3) The joint HD/EG linkages. He implies this two-way relationship between economic growth and human development suggest that nations may enter into a virtuous cycle of 
high growth and noticeable achievements in human development, or a vicious cycle of low growth and low rates improvement of human development.

Suri et al. (2011) considered the interrelationship between economic growth and human development by using panel data model over the period 1960-2001. In their study, they applied Infant Mortality short-fall Reduction (IMSR) as a proxy of human development improvement and per capita real income growth as the measure of economic growth. They categorized seventy nine developing countries (except Eastern Europe) with population of more than one million, which are divided in four groups through the plan (HD/EG).

- Countries presently in virtuous cycle,

- Countries presently in vicious cycle,

- Countries in inclined cycle towards human development,

- Countries in inclined cycle towards Economic Growth,

The Sub-Sahara African countries and some South Asian countries are in the category of vicious cycle, however, Eastern Asian countries are in the category of virtuous cycle. Their study shows that EG-lopsided quadrant was empty, which means the EG-lopsided outcome was not stable in the longrun and suggested the importance of HD improvements. On the other hand, many countries seem to be able to achieve big increase in the presence of relatively low EG, indicating that countries can sustain HD, even without large EG. They indicated that in order to achieve successful policy primarily it is essential to concentrate on human capital improvement, not only for its direct impact, but also for its feedback effect to access a stable economic growth.

Afzal et al. (2010) used annual data in their article over the period 1970-71 and 2008-09 by considering the long \& short term relationships between schooling education and economic growth in Pakistan. The consequences of their research approved the direct relationship of both Long \& short term between Schooling Education and Economic Development. Kakar et al. (2011) implemented a series of data for the period of 1980-2009 and realized that there was a long term relationship between cost of education and economic growth for the country of Pakistan. They used the Error Corrections models (ECM) and co-integration and the result of their research confirmed the long term relationship between education and economic growth.

Pradhan and Abraham (2002) used Panel Data Pattern in various Indian provinces over the period 1980-97 and investigated the role of human development policy in economic growth. The consequences of their consideration indicated that the economic growth noticeably depends on human development policies, however, allocation of resources for education by the governments is essential in order to achieve economic growth target. Noorbakhsh et al. (2001) stipulated human capital as an important factor in FDI inflows in developing countries and its implies that its importance is increasing over time. Zhang and Zhuang (2011) used Generalized Methods of Moments (GMM pattern) and considered the effect of the combination of human capital on economic growth in thirty one Chinese States over the period 1997-2009. The results indicated that higher education was more effective than the primary and the secondary education on economic growth in China. Furthermore, the role of human capital combination with local economic growth was symmetrical to the territory development. Wang and Yao (2003) in their paper namely sources of China's economic growth incorporating human capital accumulation found that the accumulation of human capital in China took placed very quickly, what's more this process had a noticeable impact on the level of welfare.

Oketch (2006) analyzed the two-way links between human resource development formed by formal schooling and economic growth and economic growth. They also considered the relationship between physical capital investment and growth by using the 2SLS method for African countries. The results indicated that in order to achieve an industrial development in African countries, it is necessary to invest on both Physical Capital as well as human capital. 
Chi (2008) concluded that the human capital indirectly and through investment on physical capital had an immense impact on economic growth in China. In addition, workers with higher education had a more efficient role in determining physical capital investment than workers with primary or secondary school education. Kendal (2012) considered the relationship between banking sector development, human capital and economic growth in states of India. The results resulted that a decline in the ratio of credit to net domestic product from $75 \%$ to $25 \%$ preceding as an average of $4 \%$ decrease in growth rate. In addition, the consequences of his study showed that human capital deepening could decrease financial restrictions. Zaman et al. (2012) considered the relationship between different financial development indicators and human capital by using annual data over the period 1975-2010 for Pakistan. The results indicated that different financial indicators played an important role on increasing human capital, and financial development indicators had a balanced long term and significant relation with human capital in Pakistan except capital market development. According to the results of Variance Decomposition Broad, money supply (M2) had the biggest share in changes in human capital measures in Pakistan. They reported variour challenges to achieve human development targets without considering financial market development in that country.

\section{Data Source}

In this study, annual time series data are used for Iranian economy over the period 1977-2001. All relevant data has been taken from the World Bank Development Indicators (WDI, 2012). All variables are expressed in natural logarithm. These indicators are named as follow:

- LHCTS: Log (School Enrollment, Tertiary (\% gross)) as a human capital indicator,

- LM2GDP: Log (Broad Money (\% of GDP)),

- LDCP : Log (Domestic Credit to private sector (\% of GDP)),

- LDCPB: Log (Domestic credit provided by banking sector (\% of GDP)), as financial development indicators.

\section{Estimation of Econometric Model and Results Interpretation}

\subsection{Unit root test}

The most important principle in creditability and capability of documented in econometrics models is to have stationary attributes on all input data. In these studies, we preferably apply the Kwiatkowski, Phillips, Schmidt and Shin (KPSS) test (1992) to recognize stationary. In this test, we have assumed the time series assumed to be (trend-) stationary under the null hypothesis. The result of this test in Table 1 shows that all variables are stationary in level (I(0))

Table 1

Kwiatkowski-Phillips-Schmidt-Shin Unit Root Test

\begin{tabular}{ccccccc}
\hline \multirow{2}{*}{ Variables } & & & & \multicolumn{3}{c}{ Asymptotic Critical Values } \\
\cline { 5 - 7 } & $(\mathrm{c}, \mathrm{t})$ & Lag Length & KPSS Statistic & $10 \%$ level & 5\% level & $1 \%$ level \\
\hline LDCP & $(1,0)$ & 4 & 0.2557 & 0.3470 & 0.4630 & 0.7390 \\
LDCBP & $(1,1)$ & 3 & 0.1366 & 0.1190 & 0.1460 & 0.2160 \\
LHCTS & $(1,1)$ & 4 & 0.1082 & 0.1190 & 0.1460 & 0.2160 \\
LM2GDP & $(1,1)$ & 2 & 0.0645 & 0.1190 & 0.1460 & 0.2160 \\
\hline
\end{tabular}

\subsection{The Econometric Model}

The relationship between financial indicators and human capital indicator by applying Vector Auto Regressive (VAR) are taken into consideration in this article through bellow formula:

$Y_{i}=A Y_{i-1}+A_{2} Y_{i-2}+\ldots . .+A_{p} Y_{i-p}+e_{1}$ 
where $Y_{i}$ is a vector including 4 variables; namely IDCP, IDCPB, IM2GDP, IHCTS. However, $P$ is the length or degree of the Regressive Process for $e_{t}$, which has been selected by Schwarz (1978) information criterion (SIC) criterion. Based on this criterion the second lag would be best.

\subsection{Impulse Response Function}

It cannot be expected that total estimated coefficients associated with variable lags become statistically significant when we estimate a Vector Auto Regressive pattern. However, it is possible that total coefficients become meaningful based on $F$ statistics. Furthermore, it is possible that the sign of different coefficient lags is not the same. In this case, the variable reaction is usually used against a positive criterion deviation shock in an equation associated with understanding the two variables behavior with each other. The impulse response function results for all variables are shown in Fig. 1 and also these results for the LHCTS variable are specifically mentioned in Table 2.

According to the impulse response function when a shock is given as much as one standard deviation on variable LDCP, the impact on LHCTS will be zero in the first year, but its impact starts from the second year, however, this impact on LHCTS in a long run would increase during this time. In addition, if a shock is given to variable (LDCPB), its impact on LHCTS would be negative from the second year, and this impact would increase during this time. If a shock is given to the variable LM2GDP its impact on LHCTS approximately starts from the second year. However, this impact would be negative and it reaches its peak on the fourth year, from this year it will have a downward trend to seventh year, and so the impact starts increasing after the seventh year.

Table 2

Response of LHCTS to Cholesky (d.f. adjusted) One S.D Innovations

\begin{tabular}{ccccc}
\hline Period & LHCTS & LM2GDP & LDCPB & LDCP \\
\hline 1 & 0.153695 & 0.000000 & 0.000000 & 0.000000 \\
2 & 0.190216 & -0.006074 & -0.008046 & 0.002193 \\
3 & 0.196225 & -0.010801 & -0.018294 & 0.005514 \\
4 & 0.195325 & -0.011689 & -0.025949 & 0.007595 \\
5 & 0.194791 & -0.010132 & -0.029066 & 0.008136 \\
10 & 0.206390 & -0.008874 & -0.029606 & 0.013383 \\
15 & 0.222965 & -0.008935 & -0.032272 & 0.016474 \\
20 & 0.243142 & -0.009700 & -0.035338 & 0.018610 \\
\hline
\end{tabular}

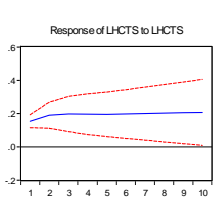

Response of LNREDP to LHCTS



Response of $L C P B B$ to HCTS
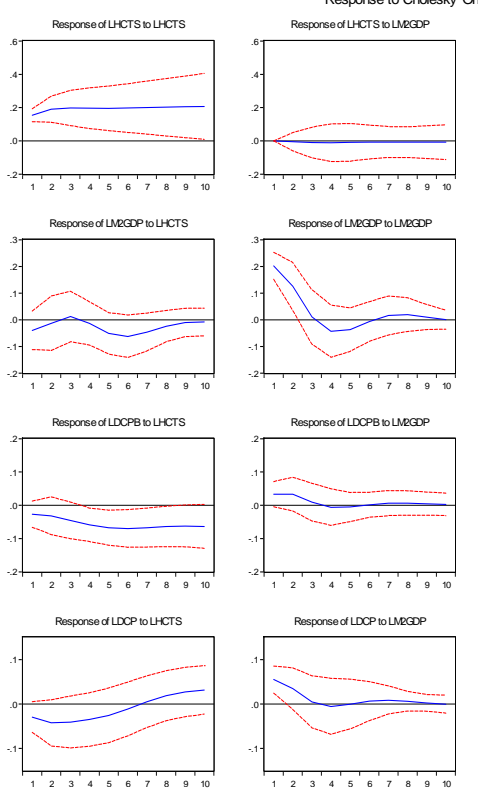

Response of $L C P B$ to L LRECDP

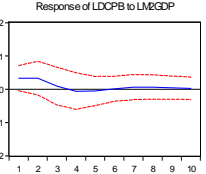

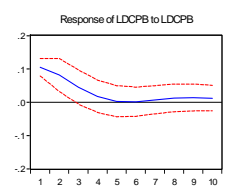
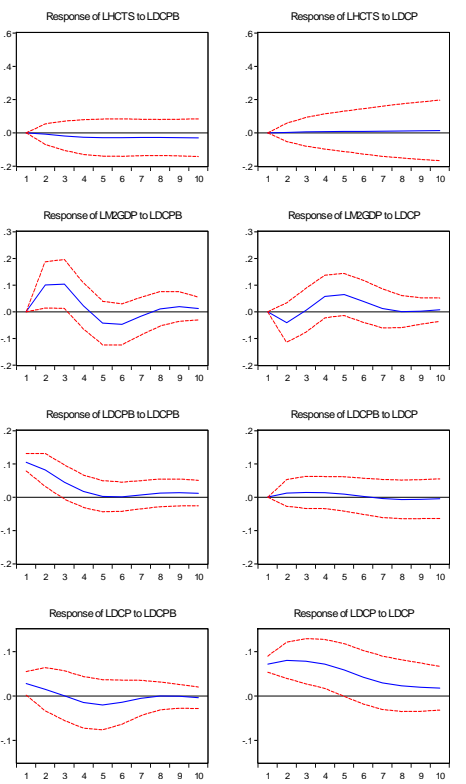

Fig. 1. Response to Cholesky One S.D. Innovations \pm 2 S.E. 


\subsection{Variance Decomposition}

It is not practical to foresee unrestricted VAR in short term, which is over- identifying, however, the aware of prediction errors is essential to clarify the interrelation among system variables. Variance Decomposition is implemented for this purpose to divide each variable fluctuated share to react to the shock given to variables pattern, for this reason we can measure a variable share on other variables changes over time. The results of Variance Decomposition are illustrated in Fig 2, and it is specifically mentioned the results of Variance Decomposition related to LHCTS variables in Table 3.

Based on Table 2 the LHCTS explanatory is increased over the time through financial variables as the second year $0.1777 \%$ of human capital variable changes are explained by financial variables and this is increased to $1.3962 \%$ in the fifth year and in long run in the tenth and the twentieth year, this impact is increased from $1.9417 \%$ to $2.2401 \%$. However, LDCP variables play the most important role to define human capital variable in Iran.

Table 3

Variance Decomposition of LHCTS

\begin{tabular}{|c|c|c|c|c|c|c|}
\hline Period & S.E. & LHCTS & LM2GDP & LDCPB & LDCP & $\begin{array}{l}\text { FINANCIAL } \\
\text { VARIABLES }\end{array}$ \\
\hline 1 & 0.153695 & 100 & 0 & 0 & 0 & 0 \\
\hline 2 & 0.244766 & 99.82233 & 0.00803 & 0.061586 & 0.108057 & 0.177673 \\
\hline 3 & 0.314478 & 99.40525 & 0.035602 & 0.155269 & 0.403883 & 0.594754 \\
\hline 4 & 0.37137 & 98.94438 & 0.067351 & 0.210412 & 0.777858 & 1.055621 \\
\hline 5 & 0.420563 & 98.60376 & 0.089939 & 0.222113 & 1.084189 & 1.396241 \\
\hline 10 & 0.620229 & 98.05832 & 0.193086 & 0.192142 & 1.556455 & 1.941683 \\
\hline 15 & 0.790009 & 97.75993 & 0.309606 & 0.180579 & 1.749883 & 2.240068 \\
\hline 20 & 0.952844 & 97.59448 & 0.38804 & 0.172946 & 1.84453 & 2.405516 \\
\hline
\end{tabular}
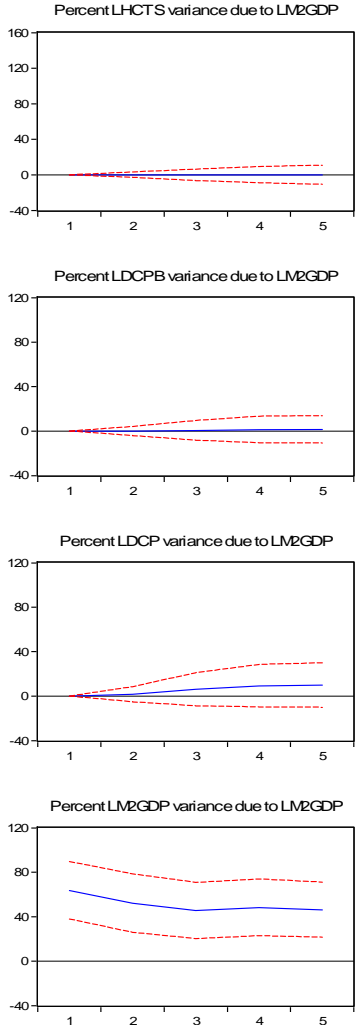

Variance Decomposition \pm 2 S.E.
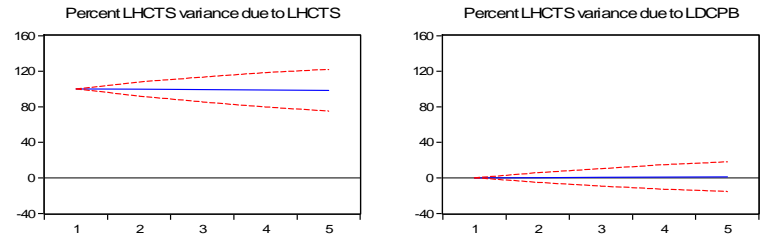

Percent LDCPB variance due to LHCTS

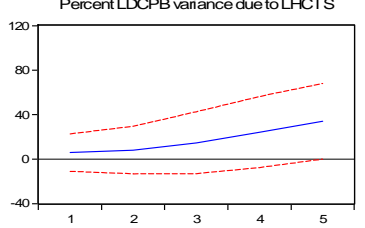

Percent LDCP variance due to LHCTS
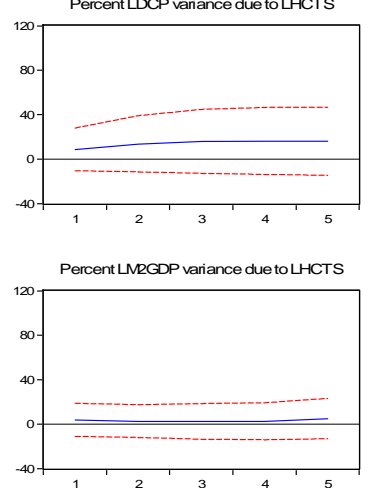
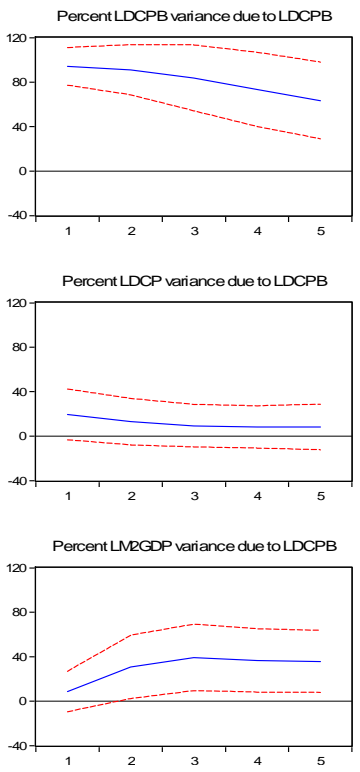

Percent LHCTS variance due to LDCP

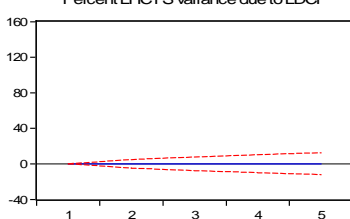

Percent LDCPB variance due to LDCP
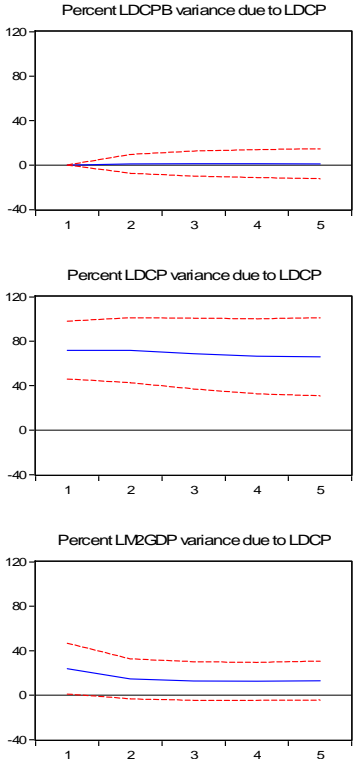

Fig. 2. Variance Decomposition 


\section{Empirical results and conclusion}

In this study, the impact of financial development on human capital in Iran has been considered by using VAR model. To this end, the "LDCP”, “LDCPB”, "LM2GDP” variables are used as financial indicators and the "LHCTS" variable was used as human development indicator over the period 1977-2010. The results of impulse-response function have indicated a positive impact of variable "LDCP" on human capital while two variables DCPB and LM2GDP have negative impact on human capital (LHCTS) in Iran. However, the results of Variance Decomposition show the importance of these variables are increasing over the time.

The role of financial development in human capital was relatively small in Iran and the consequences were in harmony with the facts of Iran economy. Hence, the education has been considered as a long run investment. However, the increase in the cash flow (M2) could lead to increase in inflation and since it reduces the present value of activities, the private sector would invest in a short-term projects. Despite the fact that the majority of banks in Iran were running by the government, the banking facilities allocation were not controlled properly and much of these allocations were allocated to government companies and organizations. The government organizations normally spend on other unnecessary affairs instead of using these facilities to promote human capital.

\section{Acknowledgements}

This paper has benefited from helpful comments of the anonymous reviewer(s) on earlier version of this work. We also gratefully acknowledge useful recommendations of Dr. Mehregan and Dr. Mirzamohammadi, all remaining errors are the author's own responsibility.

\section{References}

Afzal, M., Farooq, M.S., Ahmad, H.K., Begum, I., \& Quddis, MA. (2010). Relationship between school education and economic growth in Pakistan: ARDL Bounds testing approach to cointegration. Pakistan Economic and Social Review, 48(1), 39-60.

Al- Yousif, Y.K. (2002). Financial development and economic growth another look at the evidence from developing countries. Review of Financial Economics, 11, 131-150.

Anwar, S., \& Cooray, A. (2012). Financial development, political rights, civil liberties and economic growth: Evidence from South Asia. Economic Modelling, 29, 974-981.

Anwar, S., \& Sun, S. (2011). Financial development, foreign investment and economic growth in Malaysia. Journal of Asian Economics, 22, 335-342.

Barro, R.J., \& Lee, J.W. (2001). International data on educational attainment: updates and implications. Oxford Economic Papers, 53(3), 541-563.

Benhabib, J., \& Spiegel, M.M. (1994). The role of human capital in economic development evidence from aggregate cross-country data. Journal of Monetary Economics, 34(2), 143-173.

Birdsall, N., Pinckney, T., \& Sabot, R. (2001). Natural resources, human capital, and growth. In R. M. Auty(Ed.), Resource abundance and economic growth. Oxford: Oxford University Press.

Bittencourt, M. (2012). Financial development and economic growth in Latin America: Is Schumpeter right?. Journal of Policy Modeling, 34, 341-355.

Chi, W. (2008). The role of human capital in china's economic development: Review and new evidence. China Economic Review, 19, 421-436.

Christopoulos, D.K., \& Tsionas, E.G. (2004). Financial development and economic growth: evidence from panel unit root and cointegration tests. Journal of Development Economics. 73, 55-74.

Colombage, S.R.N. (2009). Financial markets and economic performance: empirical evidence from five industrialized economies. Research in International Business and Finance, 23, 339-348.

Deidda, L.G. (2006). Interaction between economic and financial development. Journal of Monetary Economics, 53, 233-248.

Demetriades, P., \& Hussein, K. (1996). Does financial development cause economic growth? Time series evidence from 16 countries. Journal of Development Economics, 51, 387-411. 
Dorrucci, E., Meyer-Cirkel, A., \& Santabarbara, D. (2009). Domestic financial development in emerging economies evidence and implications. Occasional Paper Series. No.102, European Central Bank . http://ssrn.com/abstract_id=1325243.

Ferda, H. (2007). The financial development and economic growth nexus for Turkey. Online at http://mpra.ub.uni-munchen. De/3566/MPRA Paper No. 3566, posted 07. November 2007/ 03:18.

Gelb, A.H. (1989), Financial policies, growth, and efficiency, Policy Planning, and Research Working Papers, No. 202 (World Bank).

Graham, D. (1995). Learning to love the Dutch disease: Evidence from the mineral economies. World Development, 23(10), 1765-1779.

Gregorio, J.D, \& Guidotti, P.E. (1995). Financial development and economic growth. World Development, 23(3), 433-448.

Gylfason, T. (2001). Natural resources, Education and economic development. European Economic Review, 45(4-6), 847-859.

Kakar, Z.k., Khalij, b.A., \& Khan, M.A. (2011). Relationship between Education and Economic Growth in Pakistan: A time series analysis. Journal of International Academic Research, 11(1), 27-32.

Kar, M., Nazlioglu, S., \& Agir, H. (2011). Financial development and economic growth nexus in the MENA countries: Bootstrap panel granger causality analysis. Economic Modelling, 28, 685-693.

Kendall, j. (2012). Local financial development and growth. Journal of Banking \& Finance, 36, 1548-1562.

Khan, M.A., \& Qayyum, A. (2007). Trade, financial and growth in Pakistan: Economic Analysis Working Papers 6(14), 1-25.

Khan, M.S., \& Senhadji, A.S. (2003). Financial development and economic growth: a review and new evidence. Journal of African Economics, 12(2), 89-110.

King, R.G., \& Levine, R. (1993). Finance and growth. Quarterly Journal of Monetary Economics, 108(3), 717-737.

Kwiatkowski, D., Phillips, P.C.B., Schmidt, P., \& Shin, Y. (1992). testing the null hypothesis of stationary against the alternative of a unit root. Journal of Econometrics, 54, 159-178.

Levine, R. (1997). Financial development and economic growth: views and agenda. Journal of Economic Literature. 35(2), 688-726.

Lucas, R. (1988). On the mechanics of economic development, Journal of Monetary Economics, 22, 3-42.

Mankiw, N.G., Romer, D., \& Weil, D.N. (1992). A contribution to the empirics of economic growth. The Quarterly Journal of Economics, 107(2), 407-437.

McKinnon, R.I. (1973). Money and capital in economic development. Washington DC: Brooking Institution.

Noorbakhsh, F., Alberto, P., \& Youssef, A. (2001). Human capital and FDI inflows to developing countries: New empirical evidence. World Development, 29(9), 1593-1610.

Odhaimbo, N.M. (2009). Finance-growth-poverty nexus in South Africa: A dynamic causality linkage. Journal of Socio-Economics, 38 (2), 320-325.

Oketch, M.O. (2006). Determinants of human capital formation and economic growth of African countries. Economics of Education Review, 25, 554-564.

Pradhan, J., \& Abraham, V. (2002). Does human development policy matter for economic growth? Evidence from Indian states. South Asia Economic Journal, 3(1), 77-93.

Psacharopoulos, G. (1985). Returns to education: A further international update and implications. Journal of Human Resources, 20, 583-604.

Psacharopoulos, G., \& Woodhall, M. (1985). Education for development: An analysis of investment choice. New York: OUP.

Ranis, G. (2004). Human development and economic growth. Center Discussion Paper NO. 887.

Ranis, G., Stewart, F., \& Ramirez, A. (2000). Economic growth and human development. World Development, 28(2), 197-219. 
1272

Romer, P.M. (1990). Human capital and growth: Theory and evidence. Carnegie - Rochester Conference Series on Public Policy, 32, 251-286.

Schumpter, J.A. (1911). The theory of economic development. Harvard University Press, Cambridge MA.

Shahbaz, M., Ahmed, N., \& Ali, L. (2008). Stock market development and economic growth: ARDL causality in Pakistan. International Research Journal of Finance and Economics, 14, 182-195.

Schwarz, G. (1978). Estimating the dimension of a model. Annals of Statistics, 6, 461-464.

Shaw, E.S. (1997). Financial deepening in economic growth. Oxford Univ. Press, NY.

Singh, T. (2007). Financial development and economic growth nexus: time series evidence from India. Applied Economics, 1-13.

Suri, T., Boozer, M.A., Ranis, G., \& Stewart, F. (2011). Paths to success: The relationship between human development and economic growth. World Development, 39(4), 506-522.

Wang, Y., \& Yao, Y. (2003). Sources of china's economic growth 1952-1999: incorporating human capital accumulation. China Economic Review, 14, 32-52.

Wayne Nafziger, E. (2006). Economic Development. Fourth Edition, Cambridge University Press.

World Bank, (2012). World Development Indicators- 2012. World bank, Washington D.C.

Zaman, k., Izhar, Z,. Mushtag Khan, M., \& Ahmad, M. (2012). The relationship between financial indicators and human development in Pakistan. Economic Modeling. 29, 1515-1523.

Zhang, C., \& Zhuang, L. (2011). The composition of human capital and economic growth: Evidence from China using dynamic panel data analysis. China Economic Review, 22, 165-171.

Zhang, J., Wang, L., \& Wang, S. (2012). Financial development and economic growth: Recent evidence from China. Journal of Comparative Economics, 40, 393-412. 